\title{
PENGEMBANGAN SISTEM INFORMASI MANAJEMEN LAYANAN PERPUSTAKAAN SMK Bandung
}

\author{
Mira sasmita
}

\author{
e-mail: mira.sasmita1999@gmail.com
}

\begin{abstract}
Abstrak
Di dalam sebuah instansi pendidikan sekarang ini tidak terlepas dari yang namanya perpustakaan, karena perpustakaan merupakan tempat yang sangat penting bagi peserta didik maupun pendidik untuk menemukan dan mencari berbagai informasi yang berkaitan dengan penegtahuan. Dengan danya teknologi maka harus mampu memanfaatkan perpustakaan untuk meningkatkan layanan perpustakaan dan aksebilitas terhadap informasi-informasi tersebut. Perpustakaan di smk bandung membutuhkan penerapan teknologi informasi sebagai sarana pendukung kegiatan perpustakaan, dan juga agar tidak ketinggalan dengan sistem informasi yang telah maju dari sebelumnya dan lebih memudahkan pengunjung dalam mencari informasi di perpustakaan tersebut. Perpustakaan smk bandung belum dapat berjalan secara efektif karena berbagai kendala yang muncul. Maka dengan adanya penelitian ini bertujuan menjadikan perpustakaan di smk bandung dapat menerapkan teknologi informasi berupa penggunaan sistem informasi terkomputerisasi dan layanan yang diberikan kepada para anggota perpustakaan. Dalam penelitian yang dilakukan maka hasil yang didapatkan adalah sistem informasi berbasis desktop, peminjaman, pengembalian, stok, layanan katalok perpustakaan dan layanan penggantian kerusakan dan kehilangan.
\end{abstract}

Kata kunci : layanan perpustakaan, sistem informasi manajemen 


\section{PENDAHULUAN}

Pada perkembangan zaman teknologi yang modern sekarang ini, dapat kita lihat informasi telah menyebar di seluruh dunia terutama di Negara Indonesia ini, dari itu masyarakat telah banyak mengunakan sistem informasi sebagai alat untuk menyelesaikan semua pekerjaannya. Misalnya dapat kita lihat di dalam dunia pendidikan saat ini telah banyak menggunakan sistem informasi seperti media pembelajaran online yaitu e-lerning, library, dan sistem informasi akademik. Pada saat ini masih banyak sekolah yang belum memanfaatkan teknologi informasi salah satunya dibagian perpustakaan, padahal perpustakaan mempunyai peran yang sangat penting bagi sekolah terutama bagi siswa- siswi dalam melancarkan kegiatan belajar mengajar untuk menambah dan memperkaya wawasan dalam ilmu penegtahuan dan teknologi informasi.

Perpustakaan merupakan salah satu fasilitas atau layanan khusus yang telah disediakan sekolah untuk menunjang proses belajar mengajar untuk mendapatkan informasi -informasi yang dibutuhkan. Perpustakaan memberikan peranan penting agar tercapainya tujuan pendidikan yang efektif sehingga perpustakaan menjadi lebih terintegrasi baik dari sisi basis maupun layanan bahan pustaka. Perpustakaan dituntu harus mampu berkembang dalam dukungan teknologi informasi dengan mengubah sistem operasionalnya dari perpustakaan konvensional menjadi perpustakaan digital.

Smk bandung adalah pendidikan swasta di kota bandung yang telah menerapkan sistem informasi untuk menjalankan aktivitas yang ada disekolahnya seperti elerning sebgaai medi pembelajaran secara online dan sistem informasi akademik untuk mengelola kegiatan sekolah. Di sekolah smk ini masih menerapkan perpustakan secara konvensional makanya beberapa masalah masih sering dihadapi. Masalah yang muncul dari mulai pendaftaran yang berdampak pada peminjaman dan pengembalian yang belum berjalan secara optimal, masalah pencatatan data dan

pengembalian juga masih menggunakan buku induk, sehingga para petugas kesulitan mengetahui siapa saja guru yang sedang meminjam dan mengembalikan buku tersebut. Dari masalah tersebut pada setiap aktivitas layanan perpustakaan tentunya akan berdampak pada penyediaan laporan perpustakaan. 


\section{Metode Penelitian}

Metode penelitian yang digunakan dalam manajemen layanan perpustakaan berbasis sistem informasi dilakukan dengan menggunakan deskriptif kualitatif untuk memecahkan permasalahan sesuai dengan faktanya. Metode yang digunakan adalah:

1. Pengumpulan data

2. Analisis sistem

3. Pengembangan sistem

4. Pengujian sistem

\section{Pembahasan}

Sistem merupakan sekumpulan elemen-elemen yang saling berkaitan dan terhubung saling bekerja sama dalam mencapai tujuan yang diharapkan. Sedangkan informasi merupakan data- data yang diolah menjadi suatu bentuk yang berarti dan bermakna bagi penggunanya. Manajemen sendiri merupakan suatu proses yang mencakup perencanaan, pengorganisasian, pengawasan, pengarahan dalam suatu organisasi untuk mencapai suatu tujuan yang diharapkan.

Sistem informasi manajemen merupakan suatu sistem yang menolah dan mengorganisasikan data informasi yang bertujuan untuk mendukung pelaksanaan dalam suatu organisasi tertentu. Sistem informasi manajemen harus dirancang berdasarkan tugas-tugas manajemen, prinsip-prinsip manajemen dan juga cara pemimpin dalam struktur organisasinya.

Menurut (agustiandra \& sabandi, 2019)sebuah sistem yang terdiri dari beberapa elemen/komponen yang saling berkaitan. Elemenelemen/komponen dari sebuah sistem ini tentu saja akan saling terkoordinasi dengan baik agar dapat mencapai tujuan yang ingin dicapai. Secara sederhana, semua sistem informasi memiliki tiga kegiatan utama di dalamnya. Aktivitas tersebut, meliputimenerima data sebagai masukan (input), kemudian data tersebut di proses dengan melakukan penghitungan, penggabungan unsur data, pemutakhiran akun, dan sebagainya, dan setelah itu akan mendapatkan informasi sebagai keluaran (output). 
Perpustakaan menurut Drs purwono adalah unit pelayanan didalam pendidikan yang bertujuan membantu tercapainya pengembangan-pengembangan tujuan lembaga pendidikan tersebut.

Tujuan dari sistem informasi manajemen adalah

1. Menyediakan informasi dalam pengambilan suatu keputusan

2. Menyediakan informasi yang digunakan di dalam proses perencanaan, pengendalian, pengevaluasian, dan juga perbaikan.

3. Menyediakan suatu informasi yang digunakan dalam menghitung harga pokok produk, jasa oleh manajemen.

Manfaat dari sistem informasi manajemen adalah:

1. Menjamin tersedianya kualitas dan keterampilan dalam memanfaatkan sistem informasi secara kritis.

2. Meningkatkan aksebilitas data yang ada secara akurat bagi para pemakai

3. Mengidentifikasi kebutuhan-kebutuhan dan keterampilan

4. Mengembangkan proses perencanaan agar lebih efektif

Sekolah SMK bandung masih menggunakan perpustakaan konvensional oleh karena itu, agar sekolah tersebut berkembang dan mencapai tujuan yang diharapkan maka sekolah tersebut harus dialihkan ke sistem perpustakaan digital agar nantinya dalam pengelolaan di perpustakaan lebih mudah dan efektif dan juga membantu para pengunjung untuk memudahkan dalam mencari bahan-bahan informasi yang diinginkan.

Perpustakaan SMK bandung dalam mengembangkannya ke bentuk perpustakaan digital maka perlu melakukan pemodelan-pemodelan terhadap sistem yang berjalan pada saat ini, agar mendapatkan kesesuaian sistem dengan aktivitas yang terjadi di perpustakaan pemodelan tersebut seperti:

a. Analisis sistem yang berjalan 
Dalam analisis yang berjalan ini terdapat dua entitas yang terlibat pada sistem layanan perpustakaan adalah siswa dan kepala sekolah, siswa berperan sebgai pengguna dan menjamin aktivitas perpustakaan, sedangkan kepala sekolah berperan sebagi penanggung jawab dan menerima laporan aktivitas perpustakaan. Layanan tersebut seperti, peminjaman buku, pengembalian buku, penggantian buku, dan penambahan buku sumbangan.

b. Evaluasi sistem yang berjalan

Untuk mengimplementasikan sistem dengan standarisasi maka perlu memecahkan atau mencari solusi permasalahan perpustakaan tersebut.

Permasalahannya:

1. Belum adanya kartu perpustakaan sebagai bukti tanda anggota perprstakaan karena tidak adanya proses pendaftaran

2. Proses pencatatan data dalam meminjam dan pengembalian buku masih menggunakan buku induk.

3. Belum adanya proses pencataan transaksi peminjaman dan penegmbalian buku.

4. Dalam penghitungan tanggal dalam proses peminjaman dan pengembalian buku masih secara manual, dan juga tidak adanya denda dalam pengembalian buku yang terlambat.

5. Belum adanya laporan-laporan perpustakaan yang akan diserahkan kepada kepala sekolah.

Untuk mengembangkan sistem informasi perpustakaan yang lebih efektif atau kebentuk modern atau bentuk digital maka yang dilakukan adalah

Solusinya adalah:

1. Merancang sistem informasi perpustakaan yang dapat mencetak formulir pendaftaran anggota, cetak anggota dan mencetak laporan data anggota perpustakaan. 
2. Merancang sistem informasi perpustakaan secara terkomputerisasi yang dapat mempermudah proses pengolahan data peminjaman dan pengembalian buku.

3. Merancang sistem informasi perpustakaan secara terkomputerisasi yang dapat mempermudah proses peminjaman dan pengembalian buku khusus guru yang disimpan dalam database

4. Merancang sistem informasi perpustakaan yang mampu menangani tanggal transaksi secara otomatis dan menghitung denda keterlambatan pengembalian buku dari sistem.

5. Merancang sistem informasi perpustakaan seperti laporan anggota, laporan daftar buku perpustakaan, laporan pengunjung, laporan pinjaman buku, pengembalian buku serta laporan dendan tanpa membutuhkan waktu yang lam.

c. Perancangan sistem yang siusulkan

Untuk perancangan sistem yang diusulkan makadilakukan proses permodelan perpustakaan tersebut seperti:

1. Pendaftaran anggota

2. Peminjaman buku

3. Pengembalian buku

4. Penggantian buku

5. Penambahan buku sumbangan

6. Peminjaman buku guru

7. Pengembalian buku guru

8. Pengisian daftar pengunjung.

d. Implementasi perancangan

Untuk mendukung pengembangan sistem perpustakaan tersebut maka perlu dukungan perangkat lunak dan perangkat jaringan.

1. Implementasi perangkat lunak perancangan

2. Implementasi perangkat keras

a. Computer server

b. Computer client 
e. Implementasi anrtarmuka

Implementasi antar muka berbasis GUI sistem informasi manajemen layanan perpustakaan merupakan media antra pengguna dengan sistem. Komponen alur sistem berupa input, proses dan output.

\section{f. Pengujian}

Hasil dari pengujian yang dilakukan membuktikan bahwa sistem informasi yang dirancang sudah mampu untuk memberikan feedback positif terhadap kasus-kasus yang diujikan.

Dari hasil penelitian terhadap sistem informasi manajemen layanan perpustakaan di SMK merdeka Bandung, maka di dapat kesimpulan bahwa dengan adanya sistem manajemen layanan perpustakaan berbasis sistem informasi ini mampu untuk memberikan dukungan pelaksanaan aktifitas layanan perpustakaan mulai dari pendaftaran, peminjaman, pengembalian, pengadaan, penggantian sampai dengan penyusunan laporan-laporan perpustakaan. Setiap aktifitas berkaitan layanan perpustakaan dapat di kelola pendataannya dengan baik. Yang berarti bahwa permasalahan yang muncul pada sistem perpustakaan yang berjalan diharapkan dapat diselesaikan dengan sistem informasi layanan perpustakaan yang dirancang ini 


\section{Daftar pustaka}

Agustiandra, V., \& Sabandi, A. (2019). Persepsi Guru Terhadap Penerapan Sistem Informasi Manajemen Akademik Di Sekolah Menengah Kejuruan (Smk) Negeri 3 Padang. Jurnal Bahana Manajemen Pendidikan, 8(1), 1-8.

Rokan, M. (2017). Manajemen Perpustakaan Sekolah. Iqra, 11(1), 88-100.

Siagian, S. (2000). Sistem Informasi Manajemen. Jakarta: Bumi Aksara. 